\title{
Apixaban-induced cutaneous leucocytoclastic vasculitis
}

\author{
Munim Khan, ${ }^{1}$ Mahmoud Y Madi (10, ${ }^{2}$ Joseph Rencic ${ }^{3}$
}

${ }^{1}$ Internal Medicine, Tufts Medical Center, Boston, Massachusetts, USA

${ }^{2}$ Hospital Medicine, University of Kansas Medical Center, Kansas City, Kansas, USA ${ }^{3}$ Internal Medicine, Boston Medical Center, Boston, Massachusetts, USA

\section{Correspondence to} Dr Mahmoud Y Madi; mmadi2@kumc.edu

Accepted 13 July 2020

\section{DESCRIPTION}

A 68-year-old woman with a medical history of hypertension, hyperlipidemia and atrial fibrillation presented to the outpatient clinic with bilateral lower extremity rash of 4 days duration. There was no associated pruritus or pain, she had no fevers or chills and her review of systems was otherwise negative. The patient had been started on apixaban a month prior to this presentation for a new diagnosis of atrial fibrillation, with no other recent changes to her medications. Her other medications included atorvastatin and hydrochlorothiazide. The patient did not have any new environmental exposures or dietary changes. Physical examination revealed diffuse palpable tender non-blanching violaceous coalescent macules and patches on both thighs and calves (figure 1) with purple bullae overlying a patch on the left dorsal fifth toe and the right medial calf. The rest of the body was spared, and the remainder of examination was unremarkable. Complete blood count, including eosinophil count, comprehensive metabolic panel, urinalysis, erythrocyte sedimentation rate and C-reactive protein, were within normal limits. Additional testing to rule out connective tissue diseases

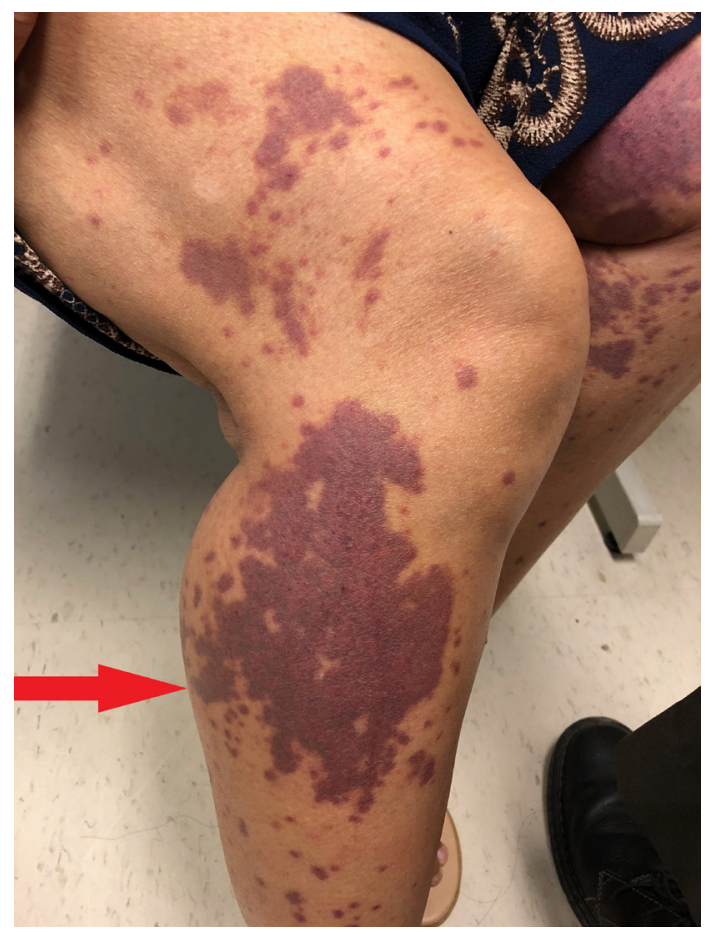

Figure 1 Diffuse palpable tender non-blanching violaceous coalescent macules and patches are noted on both thighs and calves.

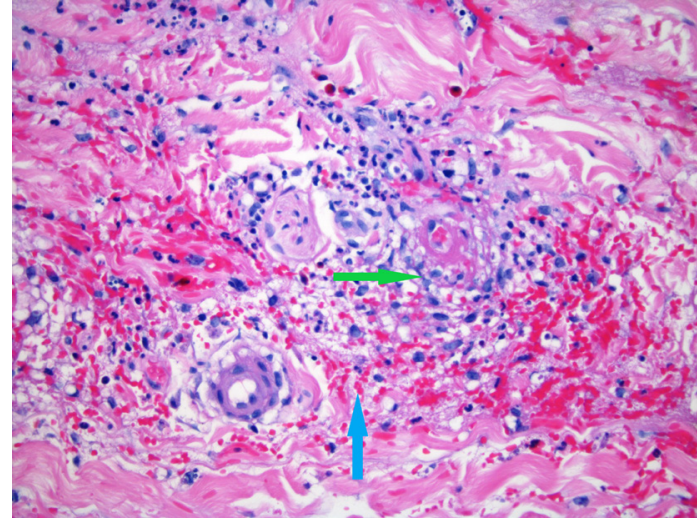

Figure 2 High-magnification H\&E staining of a punch biopsy of the rash showing the classical histological findings of leucocytoclastic vasculitis including vascular damage by the nuclear debri of infiltrating neutrophils with fibrinoid necrosis (green arrow) and red cell extravasation (blue arrow) in the dermis.

including components 3 and 4 levels, antinuclear antibodies, anti-Ro and anti-La antibodies, cytoplasmic antineutrophil antibodies and perinuclear antineutrophil antibodies were all negative. Infectious work-up including HIV, hepatitis C antibody, hepatitis B surface antigen, quantiFERON-tuberculosis, urinary chlamydia and gonorrhoea testing was negative. The patient has also had a normal screening colonoscopy and mammogram within the last year. Punch biopsy of the left shin was performed and showed pandermal leucocytoclastic vasculitis (figure 2) with no medium vessel involvement. Direct immunofluorescence testing was performed within 4 hours of obtaining the biopsy specimen and showed strong granular deposition of IgA, IgM and complement component 3 within the dermal vessel walls consistent with leucocytoclastic vasculitis. The patient scored between 5 and 7 with the Naranjo algorithm, which suggested that the likelihood that an adverse drug had occurred was probable. Given that the patient had no other recent medication changes or allergen exposure, it is likely that this presentation was a result of apixaban initiation. ${ }^{1}$ This is bolstered by the fact that her rash resolved with cessation of the medication. ${ }^{2}$ The patient was diagnosed with apixaban-induced cutaneous leucocytoclastic vasculitis after excluding other infectious, malignant and autoimmune causes of her presentation. Apixaban was discontinued and replaced with warfarin. The patient was also treated with $20 \mathrm{mg}$ of prednisone daily, which was tapered by $5 \mathrm{mg}$ every 5 days until discontinuation. Outpatient follow-up 1 and 4 months later revealed near 
Images in...

Table 1 Direct oral anticoagulants-induced cutaneous leucocytoclastic vasculitis

\begin{tabular}{|c|c|c|c|c|c|c|}
\hline Reference & Agent & Location & Severity* & $\begin{array}{l}\text { Time to } \\
\text { onset }\end{array}$ & Treatment & Time to resolution \\
\hline 2 & Rivaroxaban & $\begin{array}{l}\text { Bilateral arms, legs, } \\
\text { back and abdomen. }\end{array}$ & Moderate & 7 days & Discontinuation of rivaroxaban and methylprednisone taper. & 7 days \\
\hline 3 & Dabigatran & $\begin{array}{l}\text { Trunk, back, arms } \\
\text { and legs. }\end{array}$ & Severe & 7 days & Discontinuation of dabigatran, prednisolone and colchicine. & 5 days \\
\hline 4 & Rivaroxaban & $\begin{array}{l}\text { Bilateral lower } \\
\text { extremities. }\end{array}$ & Moderate & 10 days & Discontinuation of rivaroxaban. & 7 days \\
\hline 5 & Rivaroxaban & $\begin{array}{l}\text { Right arm and } \\
\text { bilateral legs. }\end{array}$ & Moderate & 12 days & Discontinuation of rivaroxaban. & $\begin{array}{l}\text { Not specified. Follow-up } 12 \\
\text { weeks later showed complete } \\
\text { resolution. }\end{array}$ \\
\hline 6 & Apixaban & $\begin{array}{l}\text { Bilateral arms and } \\
\text { legs. }\end{array}$ & Moderate & 7 days & Discontinuation of apixaban and prednisone taper. & Not mentioned. \\
\hline 7 & Apixaban & $\begin{array}{l}\text { Bilateral lower } \\
\text { extremities. }\end{array}$ & Mild & 10 days & Discontinuation of apixaban and prednisone taper. & 21 days \\
\hline
\end{tabular}

${ }^{*}$ Severity is determined by the extent of skin involvement with leucocytoclastic vasculitis and the presence of systemic organ dysfunction. Mild disease is limited to one to two areas of the skin with no systemic organ involvement. Moderate disease indicates more extensive skin involvement with possible ulcers, nodules or recalcitrant symptoms. Severe disease is defined as extensive skin involvement with accompanying systemic organ dysfunction. ${ }^{8}$

resolution of the rash with minimal residual hyperpigmentation. Prior case reports of direct oral anticoagulants-induced cutaneous leucocytoclastic vasculitis are summarised in table $1 .{ }^{2-7}$

\section{Learning points}

- Cutaneous leucocytoclastic vasculitis is a histopathological term used commonly to describe small vessel vasculitis that typically presents with tender palpable purpuric lesions.

- Direct oral anticoagulants are an emerging cause of cutaneous leucocytoclastic vasculitis. This is a diagnosis of exclusion.

- In cases of drug-induced cutaneous leukocytoclastic vasculitis, discontinuation of offending agent is the mainstay of treatment. Steroids may have a role in treating cases with widespread skin involvement.

Contributors All authors have sufficiently participated in the conception of the idea, development of the intellectual content, design, writing and final approval of the manuscript. MK initially interviewed, examined and photographed the patient with permission. He then wrote the initial draft of this article and included the images in it. MYM supervised the patient's hospital stay as senior resident. He planned the report of this case. He suggested submitting to the images section in BMJ Case Reports. He reviewed the initial manuscript of the article. He marked the images and added the references to the article. JR re-evaluated the patient in clinic after hospital discharge in follow-up. He helped with the analysis of the case including using the Naranjo Scale and interpreting its results to validate the significance of the reported reaction.
Funding The authors have not declared a specific grant for this research from any funding agency in the public, commercial or not-for-profit sectors.

Competing interests None declared.

Patient consent for publication Obtained.

Provenance and peer review Not commissioned; externally peer reviewed.

\section{ORCID iD}

Mahmoud Y Madi http://orcid.org/0000-0001-5759-3386

\section{REFERENCES}

1 Hofmeier KS. Hypersensitivity reactions to modern antiplatelet and anticoagulant drugs Allergo J Int 2015;24:58-66.

2 Chaaya G, Jaller-Char J, Ghaffar E, et al. Rivaroxaban-induced leukocytoclastic vasculitis: a challenging rash. Ann Allergy Asthma Immunol 2016;116:577-8.

3 Potolidis E, Mandros C, Kotsa K, et al. Dabigatran associated leukocytoclastic vasculitis. Case Rep Med 2015:2015:1-2.

4 Hasbal NB, Baştürk T, Koç Y, et al. Leukocytoclastic vasculitis associated with a new anticoagulant: rivaroxaban. Turk J Haematol 2017;34:116-7.

5 Dean R, Messer AM, Pickett M, et al. A case of leukocytoclastic vasculitis caused by novel anticoagulant rivaroxaban. Dermatol Online J 2017;23. [Epub ahead of print: 15 Nov 2017].

6 Liedke C, Nomani H, Lozeau D, et al. Apixaban-Induced leukocytoclastic vasculitis. J Clin Rheumato/ 2020. doi:10.1097/RHU.0000000000001310. [Epub ahead of print: 01 Feb 2020].

7 Nasir UB, Kumar A, Easwar A. Apixaban causing leukocytoclastic vasculitis. J Allergy Clin Immunol Pract 2018:6:1744-5.

8 Morita TCAB, Criado PR, Criado RFJ, et al. Update on vasculitis: overview and relevant dermatological aspects for the clinical and histopathological diagnosis - Part II. An Bras Dermatol 2020;95:493-507.

Copyright 2020 BMJ Publishing Group. All rights reserved. For permission to reuse any of this content visit

https://www.bmi.com/company/products-services/rights-and-licensing/permissions/

BMJ Case Report Fellows may re-use this article for personal use and teaching without any further permission.

Become a Fellow of BMJ Case Reports today and you can:

- Submit as many cases as you like

- Enjoy fast sympathetic peer review and rapid publication of accepted articles

- Access all the published articles

- Re-use any of the published material for personal use and teaching without further permission

\section{Customer Service}

If you have any further queries about your subscription, please contact our customer services team on +44 (0) 2071111105 or via email at support@bmj.com.

Visit casereports.bmj.com for more articles like this and to become a Fellow 